\title{
CONCEPTUAL ASPECTS OF MANAGEMENT OF THE FLAX COMPLEX
}

Development of the flax complex has a strategic value for Russia. In the article the content and structure of the flax complex are under study. The factors restraining its development are analyzed. The definition of the flax complex is suggested. Arguments about necessity of working out and adopting a new programme of development of the flax complex in Russia that would provide proportional and balanced development of all its sectors are adduced.

Flax fiber is the only natural raw material for the Russian textile industry. That is why flax production is of great strategic importance. In the 1990s opening boundaries for cheap import of textile and knitwear, increasing prices for material and technical resources affected the development of both flax production and the textile industry. The production of our companies turned out to be unable to meet competition in price and in quality. Because of lacking finances flax processing firms could not afford the whole payment to flax primary treating plants, the latter, in their turn, could not pay for raw material in due time, it caused decrease of a number of companies sowing flax. Besides, development of the flax complex was affected by shortage of budget financing, tightening of credit and tax policy, the state default from obligation. The management system inadequacy to the standards of market economy and the state keeping aloof from regulating functions, especially from influencing inter-sector relationship and equivalence of interchange forced growth of recession of industry in the flax complex of Russia.

In the international production chain of linen fabrics manufacturing Russia was and keeps being a deliverer of untreated fabrics, and their colouration and further processing is performed in the West Europe. Low marketability of the flax complex is also caused by the fact that in the Soviet Union since the middle of the 20th century, because of increase 
in cotton usage in the textile industry, the main part of flax fiber was used for producing technical fabrics and cotton waste that did not require high quality.

At present, because of decreasing of sow land and flax fiber croppage Russian agriculture cannot fully provide flax-processing firms with raw material in both amount and quality. Tolling shipments have become more common, when the customer delivers flax fiber for processing and gets a semiproduct. Tolling enables companies to preserve jobs, somehow, there is still not enough money for modernization.

For producing fine fabrics demanded on the world market Russian flax processing firms began importing flax fiber and linen. This factor influences the development of the flax complex both negatively and positively. On the one hand, import hinders development of Russian flax production and the primary processing of flax fiber; on the other hand, it helps us to get to the international market of linen fabrics with final production.

High exhaustion of machines and equipment, usage of obsolete technologies demand high level of material, energetic and labour content of the production that leads to decrease of competitiveness of the FC. At present an important problem is working out the strategy and tactics of the flax complex revival, competitive recovery, and providing on this basis raw material safety of the country.

In order to make the part of the state in regulating economic processes and balancing solution of problems it is necessary to form the FC as a unified control object. For that it is necessary to figure out its content as an object of state management and regulation.

The contemporary economic dictionary gives the following definition to the word "complex":

- a combination, collection of objects or actions tightly connected and interacting with each other and forming a unity;

- a group of interrelated areas, subareas, enterprises creating a product of the same nature (multisectoral complex, intersectoral complex, industrial complex) [5].

Intersectoral complexes are singled out on the basis of the analysis of technological processes of production and processing of raw material and marketing of the final product. Besides, complexes include supply and service sectors and activities.

Retrospective analysis of legal basis, scientific researches and real practice of management shows that there is no common definition of the flax complex and common approach to the content of the FC nowadays. Depending on the level of solution of the mentioned problems and research, the respective version of flax complex definition is suggested. For example, in the State programme of agriculture development and regulating markets of agricultural production, raw material and provisions for 2008-2012 and in the departmental specialpurpose programme of the Ministry of agriculture of the RF "The flax complex development for 20082010 " the flax complex is regarded as a collection of agricultural manufacturers, flax seed-production stations and flax primary treating plants.

The committee of the Chamber of Commerce and Industry of the Russian Federation on enterprise in the textile and light industry includes all flaxsowing and flax-processing organizations in the flax complex.

O.J. Novikova regards the flax complex as interdependent combination of organizations of different organizational and legal forms of property of two economic sectors of the country:

- of the agri-industrial one including seed production, flax production, flax primary processing industry, engineering of agricultural devices and equipment for flax plant, scientific research and project designing organizations, educational institutions;

- of the industrial one including companies producing yarn, untreated and finished fabrics, nonwovens, apparels and knitwear, medical production, goods and high technologies promotion system, engineering, scientific research and project designing organizations, information technologies, educational institutions [2, p. 59-64].

This definition is based on sectoral grouping of the activities of the All-Union Classifier of Economy Branches. In the All-Union Classifier of Economy Branches companies producing flax fiber (flax plants) were classified as primary flax processing companies, and the companies producing combed flax, yarn, threads, flax untreated and finished fabrics (including piece-goods made on looms), canvas and other technical and packing fabrics, gear belts, firehoses, and other technical devices (flax processing firms) - as the flax industry. This classifier is required for counting macroeconomic factors of the economy based on public property and centralized planning, and it does not reflect the changes that took place in the economy in market conditions of management. At present primary treating plants - along with primary flax processing - grow flax, make advanced processing of flax fiber and present the end product to the final customer.

On the January, 1, 2003 the All-Russia Classifier of Economy Branches was adopted. In this classifier the classifying features are the features characterizing a sphere of activity, a process (technology) of 
production, and the additional features (within the same process of production) is raw material. In the All-Russia Classifier of Economy Branches a hierarchical method of classification and a coherent method of coding are used, there is grouping in sections, subsections, classes, subclasses, groups, subgroups and kinds. This grouping enables us to point out the sphere of activity, the process (technology) of production, and the raw material associated with growing fiber flax, processing of flax production and producing fabrics out of it.

Growing fiber flax and its seeds, moistening flax stalks in order to get fiber refers to the subclass "plant cultivation" of the class "Agricultural production" of the subsection "Agriculture, hunting, and forestry" of the eponymous section. Flax processing, production of the apparels made from flax fiber are included in the subsection "Textile and clothing manufacture" of the section "Processing productions". The subsection "Textile and clothing manufacture" is divided into classes "Textile manufacture" and "Clothing manufacture".

The class "Clothing manufacture" includes sewing of any kind of clothes made of any material, any article and accessories of clothing.

The class "Textile manufacture" is more differentiated. It contains preparation for spinning and spinning of textile fibers, weaving industry, trimming of textile products, production of readymade textile products, production of textile fabric and products from it. The subclass "Spinning of textile fibers" includes "Spinning of flax fibers" that contains the following activities: flax dressing, production of flax type yarn out of flax fibers for weaving, knitting and other kinds of industry. Production of other wide-spread fabrics from the yarn made out of flax fibers is referred to the group "Production of other textile fabrics" of the subclass "Weaving industry". Grassing, colouring, printing of the textile threads, yarn, fabrics and textile products are referred to the group and subclass "Trimming of fabrics and textile products".

Manufacturing of finished textile products, bedlinen, table-cloths, linen sleeping bags, curtains, drapes, bed blankets, slipcovers for furniture and machines, canvas cloths, tents, camping devices, sails, envelopes for cars from flax fiber are referred to the subgroup "Manufacturing of finished textile products except for clothes".

Consequently, great methodological difficulty appears - where the activities of the subsection "Textile and clothing manufacture" should be referred to within the flax complex.

On the basis of the analysis of functional and synergetic connections between production processes of rotted straw and its processing we figure out 10 spheres in the flax complex:

I sphere - fields of industry producing devices for flax production and flax processing industry;

II sphere - scientific research and project designing activity in the sphere of flax growing and flax processing industry;

III sphere - flax growing;

IV sphere - primary processing of flax fiber;

V sphere - advanced processing of flax fiber;

VI sphere - manufacturing of stockings and socks and other knitted products from flax fiber;

VII sphere - clothes manufacturing form flax and flax containing fabrics;

VIII sphere - manufacturing of finished textile articles form flax and flax containing fabrics;

IX sphere - personnel training and information and consultative activity;

$\mathrm{X}$ sphere - flax complex management system.

Not all the spheres of the FC forming its structure totally correspond to the economic branch classification. In many cases the flax complex includes separate subareas and activities. Besides, it is impossible to refer activities of universal character to any complex, for example, constructing tractors, mineral fertilizers, knitted and ready-made clothes, sewing clothes, personnel training and information and consultative activity, wholesale and retail trade, if they don't have highly specialized trend.

On the assumption of the complex and the economic activities dealing with flax growing, processing flax fiber and manufacturing products out of it, we can suggest the following definition of the flax complex: the flax complex is a unity of organizations dealing with production of flax seeds and rotted straw, primary and advanced processing of flax fiber, manufacturing products out of flax fiber, flax and flax containing fabrics, machines and equipment for growing and reaping flax, processing of flax fiber, scientific research and project designing, information and personnel training activity in the sphere of flax growing, flax segment in textile, knitting and sewing industries unified of the common functional task to produce competitive production.

Thus, the flax complex is a combination of industries and activities, sectors and subsectors, and subcomplexes. The flax complex is simultaneously a part of agribusiness industry and of light industry. If we look at the flax complex from the point of view of agribusiness industry, its main goal will be growing flax seeds and rotted straw and processing of flax fiber. From the point of view of the textile industry, the flax complex contains primary and advanced processing of flax fiber, and from the point of view of clothing industry, it is manufacturing products 
from flax and flax containing yarn. According to the All-Russia Classifier of Economy Branches, the flax complex of industry is the combination of activities of flax dressing, linen yarn production, linen fabrics and products of linen yarn and fabrics.

The flax complex has its own peculiarities:

- flax complex development is of strategic importance for feasibility of high potential opportunities of the country at the domestic and world markets;

- flax growing takes place in 20 out of 89 regions of Russia, it is noticed that the number of regions growing flax is reducing;

- between the FC subcomplexes as well as between the stages of production process and marketing of the final product of the flax complex there is a functional connection;

- flax production may be used only after industrial processing, that is why it has a high level of vendibility;

- there are two stages of flax product processing - primary and advanced ones, they are territorially divided at that;

- a long investment cycle in flax production, paying flax sowing companies for delivered raw material take place after selling the product to flax plants and depend on its quality and price, and short investment cycle for flax processing firms;

- consumption of the FC production has highelastic nature and it depends on purchase power and fashion;

- there is no real flax complex management system in the Russian Federation. A lot of functions of governmental management are forfeited, and those that have been kept are dispersed between ministries, departments and committees; it leads to doubling and un-cooperation when working out management decisions and weakening of responsibility for their fulfillment.

In the flax complex every previous stage of production creates competitive advantages for the following one. Besides, every previous factor of competitive advantages is the basis for the development of the next one.

For stimulating competitive positions of the FC it is necessary to provide proportional and balanced development of all its segments, activation of work of all organizations, joining their forces on the base of clusters, integration and cooperation, improvement of the management system with the account of priority-oriented trends of development and tendencies of the world market of flax and flax containing fabrics and products.

In order to overcome industrial breakdown and differently-oriented interests it is necessary to work out the common flax complex development plan including all production and non-production spheres of it.

The organizations dealing with the FC, the Ministry of Agriculture of the RF and the Ministry of Industry and Trade of the RF should learn to make agreements with each other and advocate the interests of the complex together. They should work out and adopt a new federal special-purpose programme of flax complex development, in which complex and coherent solution of the problem of production modernization and innovation adoption will be taken into account and departmental segregation will be excluded. At the same time, any programme becomes finished in case of fix-up of its figures, when its figures are reflected in the plans of regions, ministries and departments.

In 1996 - 2001 the federal special-purpose programme "The flax complex development for 1996-2000" was being put into practice, its validity was prolonged till 2001. The State customers of the programme were the Ministry of Agriculture of the RF and the Ministry of economy of the RF. Its aim was output expansion of fiber flax and hemp, development of flax growing and flax processing industries of the agri-industrial complex, textile and light industry, and expansion of export potential and market saturation of competitive goods. However, they could not achieve the goals. When implementation of the programme only flax fiber cropping tended to grow and in 2001 it was 5,0 hwt per 1 ha, instead of 4,3 hwt in 1996. Because of shortage of cultural areas from 153,5 thousand ha in 1996 to 123,3 thousand ha in 2001 the bulk yield flax fiber decreased from 59,6 to 58,0 thousand tons. At that, the linen fabrics manufacturing increased because of raw material importing.

Somehow, scientific research and project design activities performed within the programme allowed strengthening competitive positions of the FC. However, effect of their implementation is running out. In the conditions of competitive environment successful organizational activity of the flax complex is impossible without constant technical and technological, agronomic, assortment development and renovation of the industry, without training high-qualified specialists and improving management quality. It can provide leadership in competitive ability for a long time.

At present a departmental special-purpose programme of the Ministry of agriculture of the RF "The flax complex development for 2008-2010" is being implemented. The aim of the programme is generation of the Russian raw material base and output expansion of Russian flax production. 
Implementation of the programme contemplates growth of flax seeds production, flax fiber and manufacturing flax hemp fiber. The programme involves expense subsidies for:

- purchase of elite sorts of seeds that should help to perform strain changing and strain renovation in due time;

- flax raw material production and its processing;

- co-financing of capital construction objects of State property and constituent entities of the Federation and (or) for granting special subsidies from budgets of constituent entities of the Federation to local budgets for co-financing capital construction objects of municipal property;

- current service of investments loans obtained in Russian credit organizations by agricultural manufacturers for purchasing modern technical equipment required for growing and reaping fiber flax, new highly-productive technological devices for the flax primary processing companies.

Besides, Research and Advanced Development in constructing new technologies, resource-saving and highly-productive machines and technological equipment of new generation is considered to be a part of the plan.

All in all for the programme implementation the Federal budget will give 1885,88 million rubles, including 916,25 million rubles for co-financing capital construction objects and 37,79 millions for the Research and Advanced Development. The fund of a constituent entity of the Federation must not be less than 30 per cent of the finance given for these purpose from the fund of the Federal budget.

Nevertheless, the measures considered in the programme are not enough for the flax complex surmounting the crisis. In 2008 in spite of increase of flax cultural areas and of flax fiber bulk yield we couldn't achieve the goals of the programme. The plan of sowing flax was fulfilled by $71,8 \%$, of flax fiber bulk yield by $68,2 \%$. The main cause of it was a lack of seed in flax sowing companies.

The flax complex is also affected by the financial and economic crisis. In 2008 because of sales slowdown flax processing companies could not market the product in full and settle the purchased raw materials, which caused further falling-off of flax sowing firms and cultural areas by 8 thousand ha in 2009. The flax fiber bulk was 52 thousand tons at the target code 86 thousand tons, flax seeds were produced by 3,8 times less than the volume considered by the State programme.

In the conditions of severe competition and the global economic crisis the flax complex must be dynamically developing and effectively managed segment of economy. In order to overcome the crisis situation in the flax complex it is necessary to strengthen the State support and to form the State order. The global economic crisis should be used as a means of competitive recovery, import substitution, technical and technological renovation of the industry. Rises in currencies make import production more expensive and less competitive at the Russian market. It is necessary to limit production importing at dumping prices by means of rise in imposts.

For the purpose of coherence in taking decisions, elimination of doubling in the work of the Ministry of agriculture of the RF and the Ministry of Industry and Trade of the RF and the other departments dealing with the flax complex it is necessary to strengthen the part of the the Ministry of Economic Development of the RF in working out the strategic tasks for the flax complex development.

\section{References}

1. Departmental special-purpose programme "The RF flax complex development for 2008-2010"/ URL: http://www.mcx. $\mathrm{ru}$ /documents/document/show/7653.199.htm (the date of the appeal 05.10.2009)

2. Novikova O. J. "The prospects of the flax complex companies development on advanced flax processing// Materials of the academic and research conference on the March,1, 2006 "Russia's accession to the WTO. Economic intensification flax processing complex" - Vologda, 2006. p.235.

3. All-Union Classifier of Economy Branches. 175018 [Electronic resource]: Confirmed Jan,1, 1976 (edited and confirmed by State Standards Committee of the USSR and the RF in 1977 - 1994, on June,7, 1995, on May, 28, 1997, on Oct., 29, 1997, on Jan, 15, 1999, on Aug., 31, 1999, on Feb., $15,2000)$. Access from the information and judicial system "KonsultantPlus".

4. All-Russia Classifier of Economy Branches OK 029-2007 (KDES edited 1.1) [Electronic resource]: (edited and confirmed by the order of Federal agency for technical regulation and metrology on Nov., 22, 2007). Access from the information and judicial system "KonsultantPlus".

5. Raizberg B. A., Lozovskiy L. Sh., Starodubtseva E. B. Contemporary economic dictionary. 4th publication, edited and added. M. : INFRA M., 2004. P. 480. 